\title{
A trematosauroid temnospondyl from the Middle Triassic of Jordan
}

\author{
Rainer R. Schoch \\ Staatliches Museum für Naturkunde Stuttgart, Rosenstein 1, 70191 Stuttgart; Germany; e-mail: rainer.schoch@smns-bw.de
}

\begin{abstract}
Received 29 October 2010

Accepted 21 February 2011

Published 3 August 2011

\section{Key Words}

amphibians

Anisian

mandible

phylogeny

Stereospondyli

A well-preserved mandible from the Lower Anisian Mukheiris Formation from near the Dead Sea (Jordan) proves the presence of tetrapods in the region. It is identified as a stereospondyl lower jaw sharing synapomorphies with the Trematosauroidea. It has the following combination of features: (1) Meckelian fenestra almost one-third the length of the ramus, (2) postglenoid area posterodorsally rising and robust, as long as glenoid facet, (3) preglenoid process substantially higher than medial margin of adductor chamber, (4) all teeth anteriorly and posteriorly carinate, and (5) symphysis without additional tooth rows, with a pair of unequal fangs as part of the dentary arcade, which contains unusually large teeth. The Jordan specimen shares most character-states with South African Microposaurus (size of teeth, bicarinate structure) and the Russian Inflectosaurus (preglenoid process, PGA). Phylogenetic analysis finds it to nest with $\mathrm{Mi}$ croposaurus, whereas Inflectosaurus forms an unresolved polytomy with other trematosauroids.
\end{abstract}

\section{Introduction}

Phylogenetic hypotheses, biogeographic dispersal models, and evolutionary scenarios are difficult to form but easy to reject: a single fossil may be sufficient. Previously neglected or inaccessible regions bear high potential for the discovery of such fossils, because they shed light on new faunas with unorthodox combinations of taxa, and sometimes reveal representatives of clades that were not expected in such a place and time. In the Triassic, many tetrapods reached a worldwide distribution - or at least the fossil record is good enough to document such a distribution. Still, there are regions where the record is poor, with the Middle East ranking among those. Here I report evidence for a Middle Triassic tetrapod from a region that may have been crucial for dispersal of shallow water taxa but hitherto yielded very little material: Jordan. During the Triassic, the Tethys covered vast areas of northern Gondwana, among them northern Africa and the Middle East. In deposits formed under epicontinental, shallow marine conditions, aquatic reptiles (placodonts, nothosaurs, pachypleurosaurs, thalattosaurs) are usually abundant, and a few finds have been reported from the Middle East (Rieppel et al. 1997, 1999). However, the specimen reported here stems from a temnospondyl, representing a clade of early tetrapods (stem-amphibians) believed to have inhabited a vast range of water bodies from rivers and lakes over brackish marshes to epicontinental shallow marine habitats (Schoch \& Milner 2000; Laurin \& Soler-Gijón 2001). The objective of the present study is to describe the find and elucidate its phylogenetic position among the temnospondyls.

\section{Material}

The specimen reported here was collected by Klaus Bandel, then Erlangen University, and his team in 1975 during geological field work in the Middle Triassic (Bandel \& Khoury 1981, p. 14, "bones of reptiles"). The find (SMNS 81772) comprises two complete mandible halves embedded in almost perfect articulation and only minimally crushed. The block was prepared mechanically and both elements were completely freed from sediment. The bone has a light brown to purple colour and is very well preserved. It bears numerous teeth in full articulation, suggesting little decay and no transport before burial. Unfortunately, the skull or other parts of the skeleton were not found or collected.

The locality is at the slope of Wadi Mukheiris, a major channel at the north-eastern rim of the Dead Sea (Fig. 1). The most exact data available put it as follows: $37.5 \mathrm{~km} \mathrm{SW}^{\prime}$ of Amman, $10 \mathrm{~km} \mathrm{E}^{\prime}$ of the Dead Sea (K. Bandel, personal communication 1998). The horizon, a greenish-grey, carbonaceous sandstone, falls into the lower member of the Mukheiris Formation, Lower Anisian, Middle Triassic. Following Makhlouf (2003), this member is composed of fine-grained sandstones, mudstones, marls, and carbonates that represented a tidal unit of a Tethyan strandline environment. The immediate horizon is a glauconite-bearing carbonate-rich sandstone, containing bivalves and brachiopods (Bandel \& Khoury 1981). Preparation of SMNS 81772 


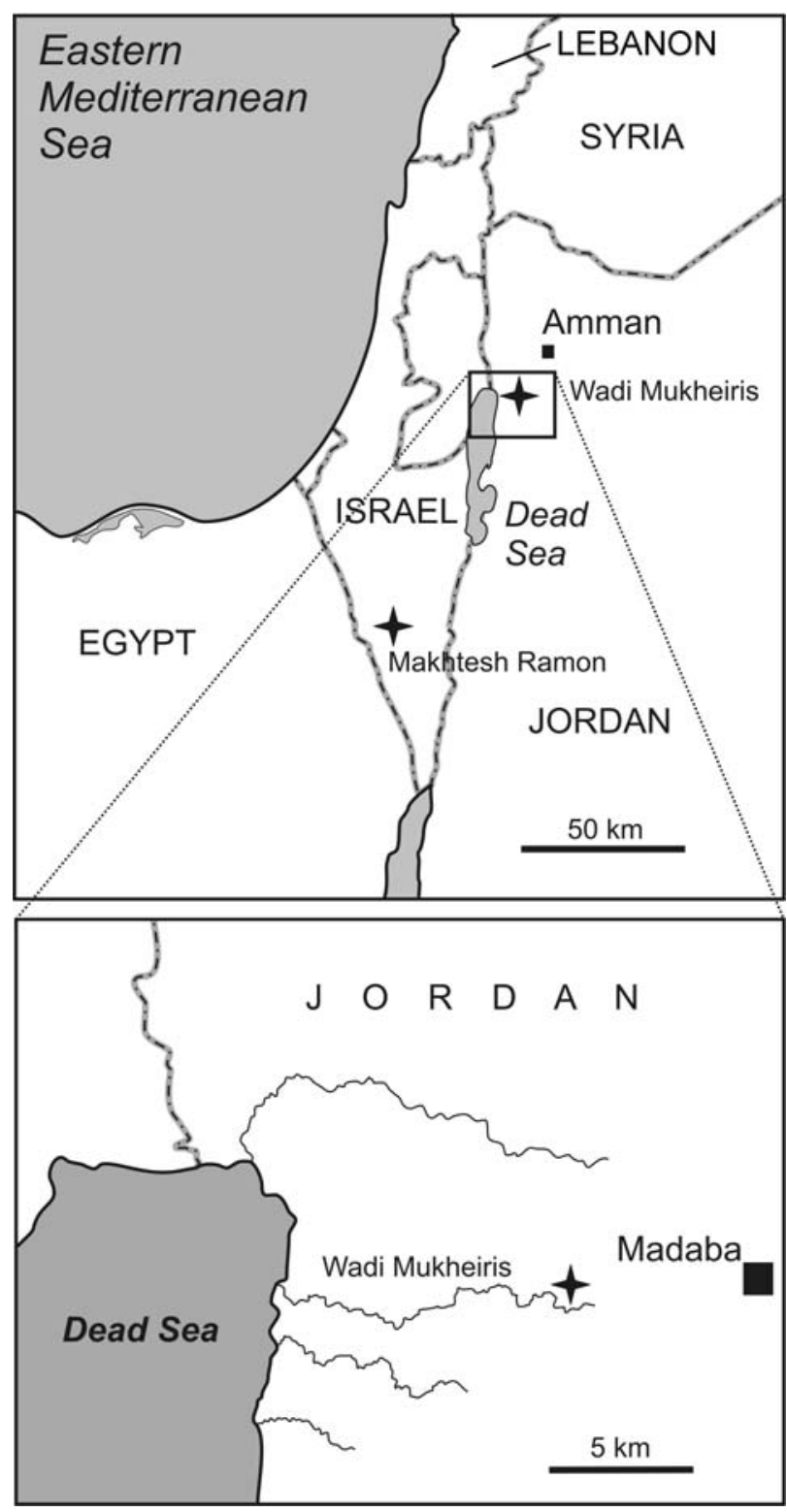

Figure 1. Location of Wadi Mukheiris (SMNS 81772) and Makhtesh Ramon (type locality of Negevodus).

yielded two small shark teeth and several tiny tetrapod teeth. Flaser bedding, wavy lamination, and ripple-marks indicate formation under conditions of shallow depth and low wave energy (Makhlouf 2003), which is confirmed by the good preservation and full articulation of teeth in the mandible.

\section{Description}

The mandible is readily identified as stemming from a stereospondyl, falling within the largest clade of Mesozoic temnospondyls. Most characteristically, the bases of all teeth are extended at right angle to the long axis of the tooth arcade, a character-state confined to postPermian stereospondyls above the rhinesuchid node (Schoch \& Milner 2000). The element as a whole is very slender, with the region anterior to the glenoid facet reaching only double the height of the anterior end (Figs 2-3). The slender and gracile appearance is further emphasized by the huge Meckelian fenestra which ranges over about one-third the mandibular length. This fenestra is further peculiar in its far anterior extension and in that the anterior end is substantially narrower than the posterior one. Also characteristic is the pronounced preglenoid process of the surangular, on the lateral (labial) side of the adductor chamber, being markedly higher than the medial wall of the chamber. The postglenoid area (PGA) is robust but not very long, gently curved posterodorsally. It resembles the condition in trematosaurs most closely, such as Trematosaurus brauni Burmeister, 1849 (observation by author) and especially the fragmentarily known Russian genus Inflectosaurus amplus Shishkin, 1960 (Shishkin 1960). Unlike the situation in capitosaurs, there is no pronounced hamate process except for a modest dorsal extension at the anteromedial frame of the glenoid facet.

\section{Dermal ornament}

The angular, splenials, and symphyseal part of the dentary are covered by a continuous and well-defined ornament, whereas the surface of the surangular has a rather irregular sculpturing (Fig. 4). The remaining regions are free of ornament and only finely pitted or striated. The angular bears the usual, radially arranged ridges originating from a point near the posterior third of the element, near the ventral margin. The ridges are moderately high and continuous, rather widely spaced. The splenial ornament is similar in the sagittal alignment of long ridges, whereas the ventral face of the symphysis is covered by numerous pits and tubercles that diverge radially from an imaginary centre near the midline suture. The lateral side of the surangular is covered by 2-3 broad elevations, close to the angular suture. The medial (lingual) surface of the ramus is smooth but bears muscle scars in places, especially on the PGA and the angular. Grooves for the lateral lines are absent.

\section{Tooth arcade}

The dentition has two immediately apparent features that are not common among stereospondyls: (1) the teeth are large throughout and not very numerous and (2) there are no additional tooth rows in the symphysis, neither a separate pair of fangs (usually anterior to the main dentary row) nor a posterior arcade as in many capitosaurs (Figs 3-4). Therefore, there is no clear-cut heterodonty as in most other temnospondyls and early tetrapods, but rather a gradual increase in size towards the symphysis. Although different in size, all teeth except for the two anteriormost ones have crowns that are curved inwards. As in most post-rhinesuchid stereospondyls, the tooth bases are transversely extended and the teeth are so closely set that no space remains on 

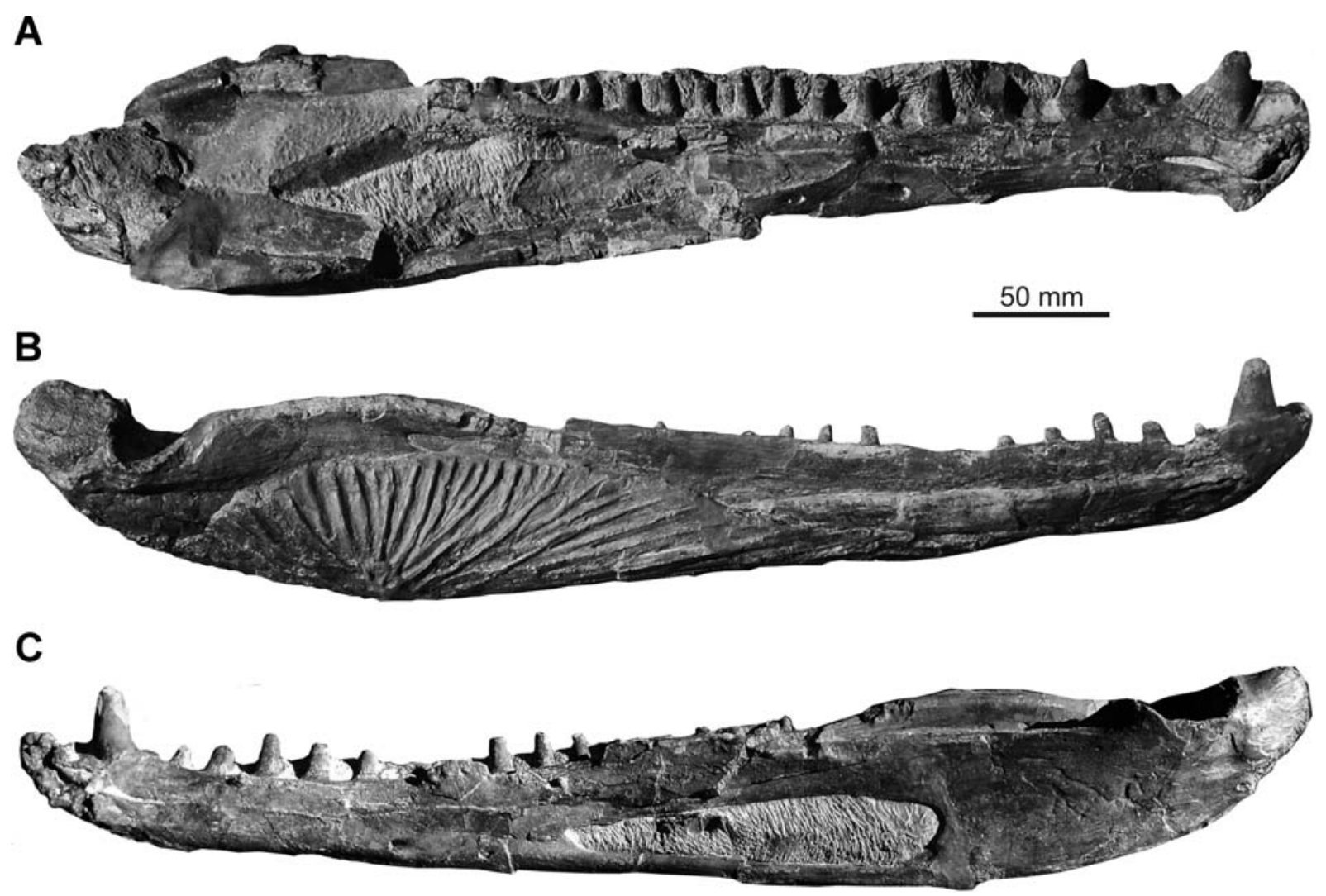

Figure 2. Mandible halves of the Mukheiris trematosauroid (SMNS 81772). A. Left half; B-C. Right halves.

the dental arcade. However, at mid-height, each tooth is anteroposteriorly broadened, with the anterior and posterior faces carinate. All teeth are labyrinthodont as visible by parallel grooves resulting from infolded enamel. The right mandibular ramus has space for at least 33 teeth, with 15 in use and one in the process of replacement, whereas the left ramus has at least 37 sockets with 18 teeth present. The discrepancy results from the lack of the posteriormost part of the dentary on the right side. The size range of the teeth is substantial, with the anterior two forming true fangs, followed by three very small teeth, 16-18 larger teeth and finally smaller teeth again. It is further peculiar that the anteromedial fang has a much larger socket than its neighbour, a pattern known from other trematosaurids (Schoch 2006) and, although to a lesser extent, capitosaurs (Schoch \& Milner 2000).

\section{Symphysis}

In dorsal view, the symphysis forms a posteriorly extended and rather flat, semilunar area. It is substantially longer than in rhinesuchids, lydekkerinids, plagiosaurids, and capitosaurs and (in lateral view) also markedly lower than in these. The sagittal cross-section of the symphysis slopes posteroventrally at an angle of $45^{\circ}$. There is no space for teeth other than the two fangs, which differ in size. The two fangs occupy the complete dorsal area of the symphysis. The general configuration of the symphysis resembles that of Bukobaja and Trematolestes closely (Ochev 1966; Schoch 2006). The symphysis is formed by two dermal bones, the dentary and splenial, which are separated on the medial side by an elongate fissure; a mentomeckelian ossification (Schoch \& Milner 2000) is absent.

\section{Meckelian fenestra}

The present specimen has the second largest Meckelian fenestra known among temnospondyls (Fig. 3), exceeded only by that of Callistomordax (Schoch 2008). It is substantially longer than the Meckelian fenestrae in Mastodonsaurus and Cyclotosaurus but resembles their outline, and it is likewise longer than those of Trematosaurus and Aphaneramma, in addition having a higher posterior end. In SMNS 81772, the fenestra measures slightly less than one third the length of the entire ramus, with a rounded posterior and a pointed anterior end. The highest point of the opening falls within its posterior third.

\section{Postglenoid area}

In a useful paper, Jupp \& Warren (1986) studied the retroarticular region of Mesozoic temnospondyls, referring to it as the post-glenoid area (PGA). They distinguished two structural types, defined by the number of elements contributing to its formation. The Jordan specimen is similar to their type 2 , in which the region is composed of three elements: the surangular on the lat- 

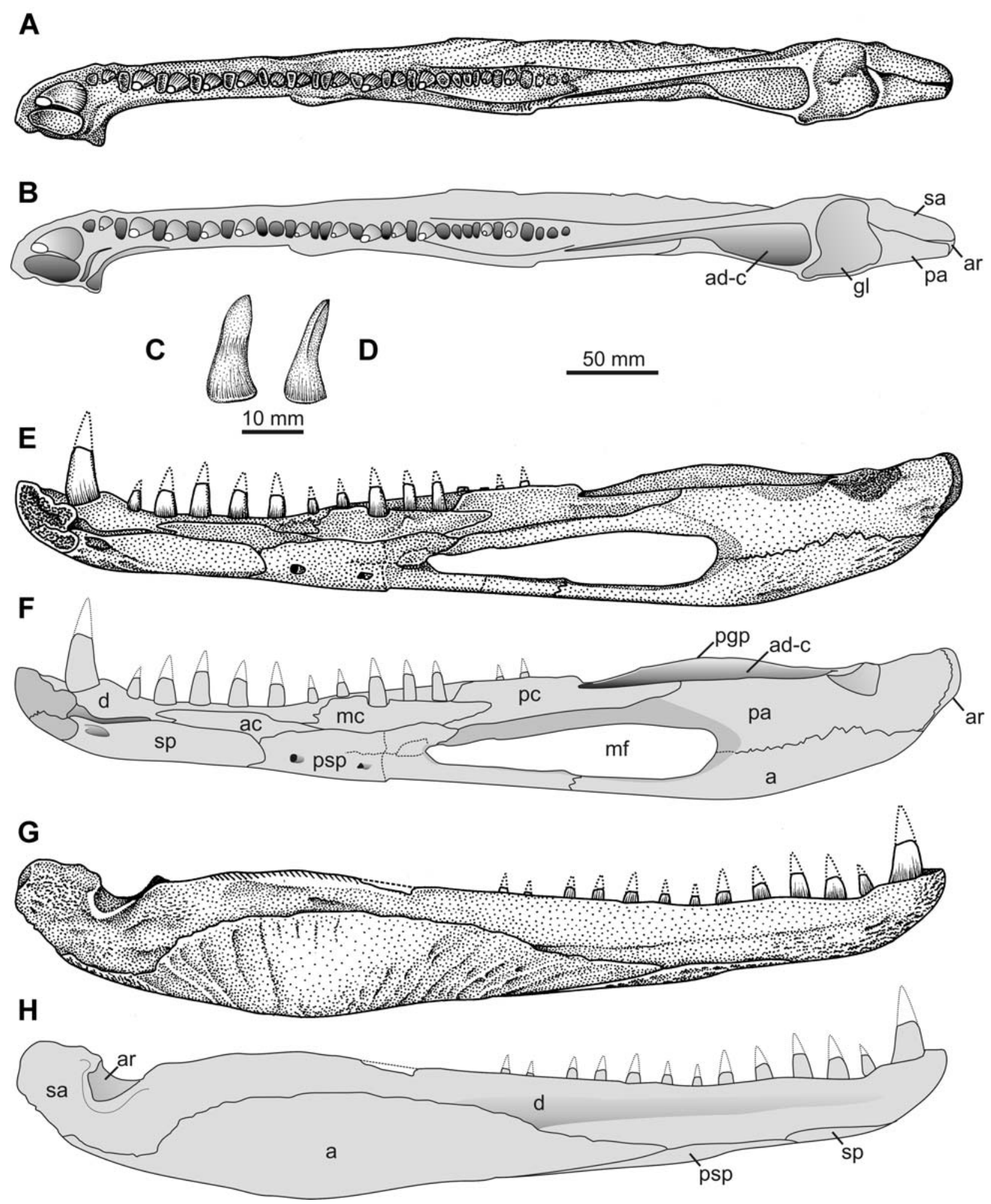

Figure 3. Interpretation of the original right trematosauroid mandible (SMNS 81772) from the Mukheiris Formation. A-B. Dorsal view; C-D. Close-up of dentary tooth in lateral (left) and anterior (right) views; E-F. Medial view; G-H. Lateral view. Abbreviations: a - angular; ac - anterior coronoid; ad-c - adductor chamber; ar - articular; d - dentary; gl - glenoid; mc - medial coronoid; mf - Meckelian fenestra; pa - prearticular; pc - posterior coronoid; pgp - preglenoid process; psp - postsplenial; sa surangular; sp - splenial.

eral side, the prearticular on the medial side, and the articular wedged in between. The articular forms a thin, sheet-like posterior projection, consistent with Jupp \& Warren's (1986) description. Yet unlike their example for type 2 mandibles, the surangular and prearticular contribute equally to the postglenoid area in dorsal view, and both elements extend equally far posterior, covering the articular almost completely from both sides. 
A

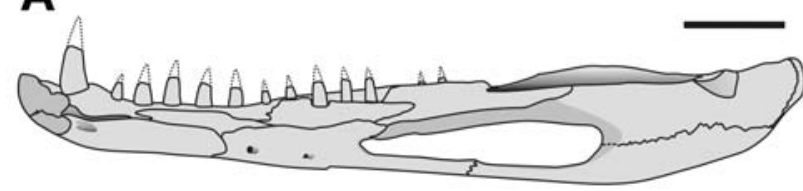

B

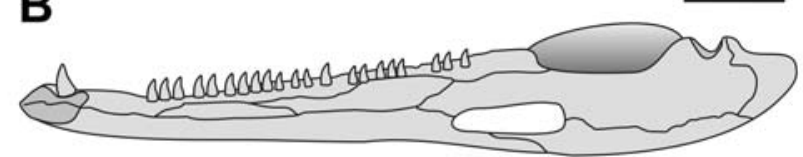

C

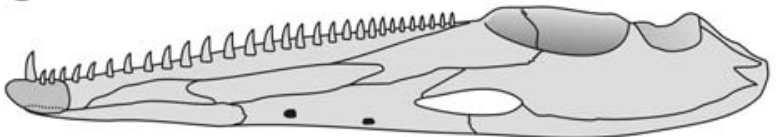

D

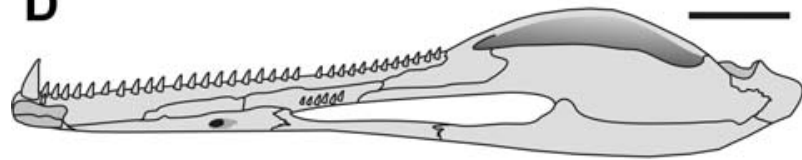

E

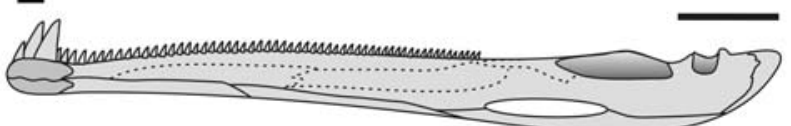

Figure 4. Comparison of SMNS 81772 with other stereospondyl mandibles. A. SMNS 81772; B. Inflectosaurus amplus Shishkin, 1960 (after Shishkin 1960); C. Metoposaurus diagnosticus (Meyer, 1842) (after Sulej 2007); D. Callistomordax kugleri Schoch, 2008 (after Schoch 2008); E. Trematolestes hagdorni Schoch, 2006 (after Schoch 2006). Scale: 20 mm.

In SMNS 81772, the PGA is relatively longer than in most rhinesuchids but substantially shorter than in capitosaurs, brachyopoids, and plagiosaurids. It measures about the length of the glenoid facet, a feature typical of trematosauroids. In dorsal view, the PGA is triangular, with a rounded dorsal surface. Unlike in capitosaurs, there is no groove for the attachment of the depressor muscle, and the characteristic pit (supposedly attaching a tendon in other stereospondyls) is also absent. In lateral view, the outline of the PGA is most similar to that of Inflectosaurus amplus (Shishkin 1960) and to a somewhat lesser degree, Trematolestes hagdorni Schoch, 2006 (Schoch 2006) and Trematosaurus brauni (Schoch \& Milner 2000).

\section{Coronoid and splenial series}

The coronoids form a continuous series of dermal bones, with the posterior coronoid being the longest element. They are all edentulous, lacking even patches of weak shagreen or shallow ornament as other stereospondyls often have in formerly tooth-bearing regions. The anterior coronoid is the shortest and most slender element, its posterior end wedging between the middle coronoid and postsplenial. In comparison, the splenials are more massive and higher than the coronoids, with the splenial being larger than in most other stereospondyls.

\section{Phylogenetic position}

Although the new find provides information only from one particular body region, the good preservation and wide range of characters defined in temnospondyl mandibles should permit some conclusions about the phylogenetic position of the new find. In early tetrapods, restricted data sets from certain body regions have been analyzed in recent years, indicating that regions other than the dermal skull may also add significantly to phylogenetic analyses (Ahlberg \& Clack 1998; Schoch 1999; Witzmann \& Schoch 2006; Pawley 2007; Ruta \& Bolt 2009).

\section{Analysis}

The present phylogenetic analysis is based on character lists and data sets that developed during the last three decades, starting with Warren \& Black (1985), Milner (1990), Yates \& Warren (2000), Damiani (2001), Steyer (2002), Damiani \& Yates (2003), and Schoch (2006, 2008). Character-codings are based on the data matrix of Schoch (2008), to which three new taxa were added (Inflectosaurus amplus, Microposaurus casei Haughton, 1925, and the Jordan specimen). Trematosaurus and the lonchorhynchines are too poorly known in the mandible region to add significant data at the present stage. The analysis included 20 taxa and 102 characters (see Appendix). It was run in the branch-and-bound mode, giving eight most parsimonious topologies and a tree length of 208 steps (CI: 0.531, RI: 0.708, RC: 0.376). The resulting consensus (Fig. 5A) has two unresolved nodes: (1) the short-faced stereospondyls ("rhytidosteans"), capitosaurs, and trematosaurs form a trichotomy, and (2) within the trematosaurs, above Lyrocephaliscus, a polytomy remains between (a) Trematolestes, (b) Almasaurus, (c) Inflectosaurus, (d) Microposaurus + Jordan taxon, and (e) Callistomordax + Metoposauridae. Otherwise, the results are similar to those of Schoch's (2008) analysis, with a clade formed by the short-faced stereospondyls (rhytidosteids, brachyopids, chigutisaurids, Laidleria, and plagiosaurids) and a large trematosaurian clade including the metoposaurids and their sister-taxon Callistomordax.

\section{Significance of results}

The present analysis is limited by a range of problems. One is the large extent of missing data, especially on the postcranium of trematosaurs and "rhytidosteans". More grave still is the particularly poor knowledge of the three taxa added in the present analysis. A further problem forms the vast number of convergences, as indicated by numerous cases of conflicting evidence. 


\section{A}

\section{S T E R E O S P O N D Y I}

\section{TREMATOSAUROIDEA}

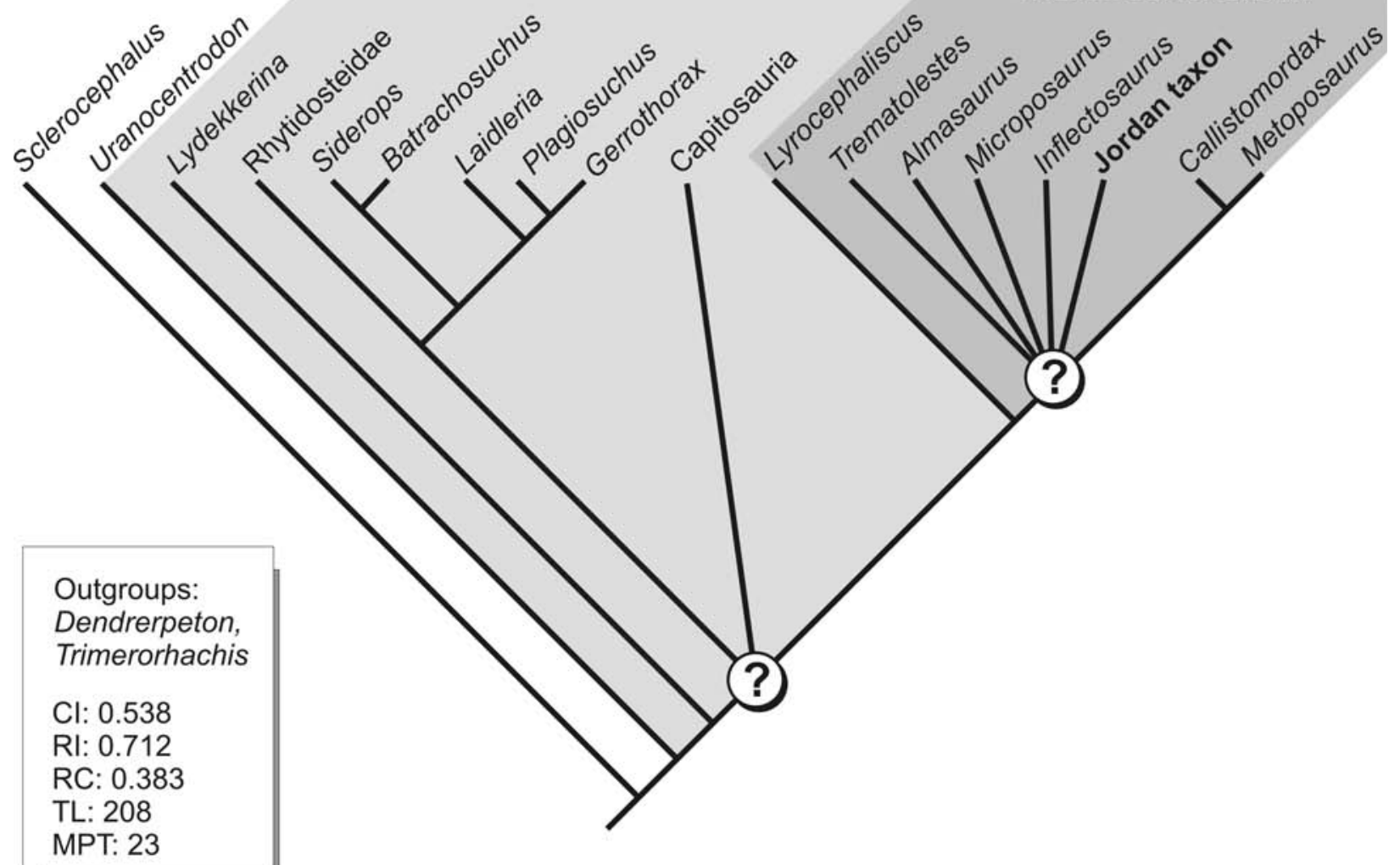

B

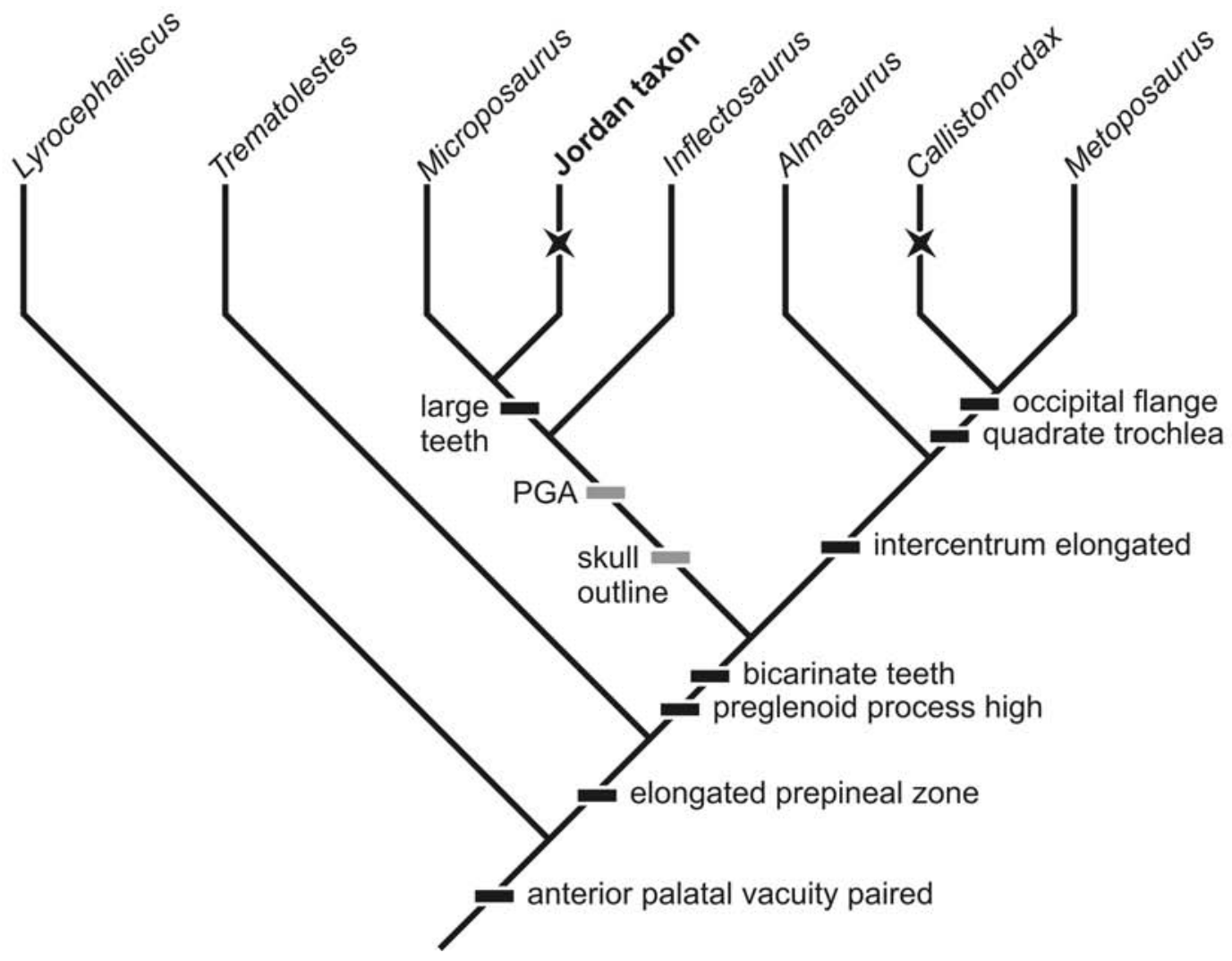

Figure 5. A. Consensus of eight most parsimonious trees, as found by PAUP 3.1 (heuristic search); B. Preferred phylogeny of trematosauroids, with characters discussed in the text mapped (black: synapomorphic; grey: homoplastic; asterisk: Meckelian fenestra enlarged). 
Keeping these general problems in mind, the significance of the present analysis may be twofold. First, it confirms earlier results that the crown of the stereospondyls is formed by three major groups, the shortfaced "rhytidosteans", the capitosaurs, and the trematosauroids sensu Damiani \& Yates (2003). In various permutations, this three-taxon pattern emerged already in Yates \& Warren's (2000) analysis and studies following that work (Damiani \& Yates 2003; Schoch 2006, 2008; Maganuco \& Pasini 2009). The major question arising from this pattern is the relationship of the three to each other, and here a consensus is far from being in reach. The present results highlight that difficulty in failing to resolve the three-taxon statement between capitosaurs, trematosaurs, and "rhytidosteans". A second result of the present study is that mandibular characters indeed add significant signals to phylogenetic analysis of temnospondyls, confirming earlier work by Jupp \& Warren (1985) and Ruta \& Bolt (2009). In addition, a sister-group relationship between Microposaurus and the Jordan specimen is supported by the present analysis, although their nesting within the trematosauroids is not clear. The position of Inflectosaurus is equivocal, despite close resemblance of the mandible of that taxon to the Jordan find. The different variants, reflected by the alternative trees, include versions in which Microposaurus, the Jordan taxon, and Inflectosaurus form a clade (adopted here for the preferred phylogeny presented in Figure 5B), as well as other groupings in which either is more closely related to the Metoposauridae and Callistomordax; Steyer (2002) arrived at a similar result. At any rate, cladistic analysis supports the attribution of SMNS 81772 to the Trematosauroidea sensu Damiani \& Yates (2003) and indicates a close relationship with the South African genus Microposaurus (Fig. 5A).

\section{Discussion and conclusions}

\section{Is the Mukheiris find another specimen of Negevodus?}

The Jordan specimen is not the first temnospondyl from the Middle East: Brotzen (1956) reported fragments from the Lower Anisian Beneckeia Beds of Makhtesh Ramon, Negev (Israel), some $145 \mathrm{~km} \mathrm{SW}$ of Wadi Mukheiris. Whereas these finds are indeterminate, the discovery of an anterior temnospondyl palate in the same beds at Makhtesh Ramon proves more significant. The specimen was first reported by Mazin (1986) who considered it a placodont and named it $\mathrm{Ne}$ gevodus ramonensis. Zanon (1991) then identified the find as a temnospondyl snout fragment, providing a tentative restoration of the anterior skull. He emphasized the similarity of Negevodus to metoposaurids, based on the morphology of the paired anterior palatal vacuity and a range of other features. In fact, these features are also shared by trematosauroids other than the metoposaurids, notably Microposaurus, Platystega, and Lyrocephaliscus which come especially close in the morphology of the anterior palatal vacuity and choana. However, two conspicuous differences exist at least between Microposaurus and Negevodus, (1) the non-carinate surface of all teeth in Negevodus, and (2) the presence of a transvomerine tooth row in the latter. Still, the type of Negevodus is too fragmentary to permit distinction from or referral to existing trematosauroid taxa, which is why it was omitted from the phylogenetic analysis.

In conclusion, the available evidence indicates that the type of Negevodus and the Jordan specimen both pertain to the Trematosauroidea, but the different structure of their teeth - both fangs and regular marginal dentition - suggests that they represent separate taxa. Whereas the Jordan specimen shares the bicarinate teeth, their size and arrangement with Microposaurus and Inflectosaurus, Negevodus is more similar to Lyrocephaliscus and Platystega in the dentition and morphology of the openings in the anterior palate than to Microposaurus or other trematosauroids. However, both Negevodus and the Jordan specimen share a range of apomorphic features with all these broad-skulled trematosauroids, suggesting that they fall into the same grade within the Trematosauroidea.

\section{Implications}

The new find is the first from Jordan and provides substantial evidence for the presence of large trematosauroids in the neighbourhood of this shallow marine environment. The excellent in-situ preservation of teeth indicates that the mandible was not transported over a longer distance. In subtropical climates similar to the preserved situation, skeletons decay at a fast pace, which in turn indicates that the mandible must have been buried rapidly. Ecologically, little is known of trematosauroid preferences and habits. However, the group stands out as the one of which several taxa were found in marine palaeoenvironments, indicating euhaline habits for at least some of its constituent species (Hammer 1987; Schoch \& Milner 2000; Warren 2000).

In terms of biogeography, trematosauroids form an especially widespread group (Schoch 2000; Warren 2000). Metoposaurids were a distinctive clade of uniform, large stereospondyls and are common in North America, Europe, North Africa, and Madagascar (Hunt 1993; Schoch \& Milner 2000; Sulej 2007; Witzmann \& Gassner 2008). Other trematosauroids are morphologically more divergent and dispersed across Pangaea: the long-snouted lonchorhynchines are known from Arizona, Nova Scotia, Spitsbergen, Europe, Pakistan, India, Australia, and eastern maritime Russia (Shishkin \& Lozovsky 1979; Welles 1993), the platystegids are confined to Spitsbergen (Säve-Söderbergh 1936), the apparently related Tertremoides, Bukobaja, and Trematolestes are present in Madagascar, Russia, and Germany (Ochev 1966; Lehman 1979; Schoch 2006), 
whereas the enigmatic genera Microposaurus and Inflectosaurus are each restricted to South Africa (Damiani 2004) and Russia (Shishkin 1960). Provided that sharedderived characters of the Jordan specimen with Microposaurus and the morphological resemblance with Inflectosaurus testify close relationship, SMNS 81772 would indeed bridge the huge geographical gap between the two occurrences. The next find from the wider region is a small capitosauroid mandible from the Upper Triassic of northern Ethiopia (Warren et al. 1998), and the lonchorhynchine trematosaurid Aphaneramma kokeni (Huene, 1920) from the Salt Range in Pakistan (Huene 1920), both taxa not closely related to the Jordan taxon.

The present find highlights how important specimens from hitherto neglected or poorly accessible regions are and that they hold the potential to refine or refute existing hypotheses. Considering the articulation of teeth in the Jordan specimen, which suggests that the taxon was autochthonous at the locality, intensified search for more specimens appears promising.

\section{Acknowledgements}

I thank Klaus Bandel for donating the specimen to the SMNS, Rupert Wild for drawing my attention to the find, and Achim Lehmkuhl for his skilfull preparation. I am grateful to Jenny Clack, Andrew Milner, and Marcello Ruta for their thoughtful reviews and the editor for helpful suggestions.

\section{References}

Ahlberg, P. E. \& Clack, J. A. 1998. Lower jaws, lower tetrapods - a review based on the Devonian genus Acanthostega. - Transactions of the Royal Society of Edinburgh: Earth Sciences 89: 11-46.

Bandel, K. \& Khoury, H. 1981. Lithostratigraphy of the Triassic in Jordan. - Facies 4: 1-26

Brotzen, F. 1956. Stratigraphical studies on the Triassic vertebrate fossils from Wadi Ramon, Israel. - Arkiv för Mineralogi och Geologi 2: 191-217.

Burmeister, H. 1849. Die Labyrinthodonten aus dem bunten Sandstein von Bernburg. 1. Abtheilung. Trematosaurus. Reimer, Berlin.

Damiani, R. J. 2001. A systematic revision and phylogenetic analysis of Triassic mastodonsauroids (Temnospondyli, Stereospondyli). Zoological Journal of the Linnean Society London 133: 379-482.

Damiani, R. J. 2004. Cranial anatomy and relationships of Microposaurus casei, a temnospondyl from the Middle Triassic of South Africa. - Journal of Vertebrate Paleontology 24: 533-541.

Damiani, R. J. \& Yates, A. M. 2003. The Triassic amphibian Thoosuchus yakovlevi and the relationships of the Trematosauroidea. Records of the Australian Museum 55: 331-342.

Hammer, W. R. 1987. Paleoecology and phylogeny of the Trematosauridae. In McKenzie, G. D. (ed.). Gondwana Six: stratigraphy, sedimentology, and palaeontology. - American Geophysical Union: Geophysical Monographs 41: 73-83.

Haughton, S. H. 1925. Descriptive catalogue of the Amphibia of the Karroo system. - Annals of the South African Museum 12: 6577.

Huene, F. von 1920. Gonioglyptus, ein altriassischer Stegocephale aus Indien. - Acta Zoologica 1: 433-464.

Hunt, A. P. 1993. Revision of the Metoposauridae (Amphibia: Temnospondyli) and description of a new genus from Western
North America. - Bulletin of the Museum of Northern Arizona 59: 67-97.

Jupp, R. \& Warren, A. A. 1986. The mandibles of the Triassic temnospondyl amphibians. - Alcheringa 10: 99-124.

Laurin, M. \& Soler-Gijón, R. 2001. The oldest stegocephalian from the Iberian Peninsula: evidence that temnospondyls were euryhaline. - Comptes Rendus Académie des Sciences de la Vie 324: 495-501.

Lehman, J.-P. 1979. Nouveaux trématosaures de Madagascar: les stégocephales Malgaches et leur paléoecologie. - Annales de Paléontologie 65: 35-53.

Maganuco, S. \& Pasini, G. 2009. A new specimen of trematosaurian temnospondyl from the Lower Triassic of NW Madagascar, with remarks on palatal anatomy and taxonomic affinities. - Atti Societá italiana Museo Civico di Storia Naturale Milano 150: 91-112.

Makhlouf, I. M. 2003. Fluvial/tidal interaction at the southern Tethyan strandline during Triassic Mukheiris times in central Jordan. Journal of Asian Earth Sciences 21: 377-385.

Mazin, J.-M. 1986. Negevodus ramonensis n. g. n. sp., un nouveau placodonte du Trias moyen du Negev (Israël). - Comptes Rendus de l'Académie des Sciences, Paris, Série II 302: 927-929.

Meyer, H. von 1842. [Letter on Mesozoic amphibians and reptiles]. Neues Jahrbuch für Mineralogie, Geologie und Paläontologie 1842: 301-304.

Milner, A. R. 1990. The radiations of temnospondyl amphibians. In Taylor, P. D. \& Larwood, G. P. (eds). Major evolutionary radiations. Clarendon Press, Oxford: pp. 321-349.

Ochev, V. I. 1966. Systematics and Phylogeny of Capitosauroid Labyrinthodonts. Saratov State University Press, Saratov [In Russian].

Pawley, K. 2007. The postcranial skeleton of Trimerorhachis insignis Cope, 1878 (Temnospondyli: Trimerorhachidae): a plesiomorphic temnospondyl from the Lower Permian of North America. - Journal of Paleontology 81: 873-894.

Rieppel, O., Mazin, J.-M. \& Tchernov, E. 1997. Speciation along rifting continental margins: a new nothosaur from the Negev (Israel). - Comptes Rendus de l'Académie des Sciences, Paris, Série II 325: 991-997.

Rieppel, O., Mazin, J.-M. \& Tchernov, E. 1999. Sauropterygia from the Middle Triassic of Makhtesh Ramon, Negev, Israel. - Fieldiana: Geology 40: 1-85.

Ruta, M. \& Bolt, J. R. 2009. The brachyopoid Hadrokkosaurus bradyi from the early Middle Triassic of Arizona, and a phylogenetic analysis of lower jaw characters in temnospondyl amphibians. Acta Palaeontologica Polonica 53: 579-592.

Säve-Söderbergh, G. 1936. On the morphology of Triassic stegocephalians from Spitsbergen, and the interpretation of the endocranium in the Labyrinthodontia. - Kunglik Svensk Vetenskapsakademiens Handlingar 16: 1-181.

Schoch, R. R. 1999. Studies on braincases of early tetrapods: structure, morphological diversity, and phylogeny. 2. Dissorophoids, eryopids, and stereospondyls. - Neues Jahrbuch für Geologie und Paläontologie Abhandlungen 213: 289-312.

Schoch, R. R. 2000. Biogeography of stereospondyl amphibians. Neues Jahrbuch für Geologie und Paläontologie Abhandlungen 215: 201-231.

Schoch, R. R. 2006. A complete trematosaurid amphibian from the Middle Triassic of Germany. - Journal of Vertebrate Paleontology 26: $29-43$.

Schoch, R. R. 2008. A new stereospondyl from the Middle Triassic of Germany, and the origin of the Metoposauridae. - Zoological Journal of the Linnean Society 152: 79-113.

Schoch, R. R. \& Milner, A. R. 2000. Stereospondyli. In Wellnhofer, P. (ed.). Handbuch der Paläoherpetologie, vol. 3B. Pfeil, Munich: pp. 1-203.

Shishkin, M. A. 1960. Inflectosaurus amplus, a new Triassic trematosauroid. - Paleontologiceskij Zhurnal 1960: 130-148 [In Russian]. 
Shishkin, M. A. \& Lozovsky, V. R. 1979. A labyrinthodont from the Triassic of southern Primovye. - Doklady Akademij Nauk SSSR 246: 201-205 [In Russian].

Steyer, J.-S. 2002. The first articulated trematosaur 'amphibian' from the Lower Triassic of Madagascar: Implications for the phylogeny of the group. - Palaeontology 45: 771-793.

Sulej, T. 2007. Osteology, variability and evolution of Metoposaurus, a temnospondyl from the Late Triassic of Poland. - Palaeontologia Polonica 64: 29-139.

Warren, A. A. 2000. Secondarily aquatic temnospondyls of the Upper Permian and Mesozoic. In Heatwole, H. \& Carroll, R. L. (eds). Amphibian Biology, Vol. 4, Palaeontology: The Evolutionary History of Amphibians. Surrey Beatty \& Sons, Chipping Norton: pp. 1121-1149.

Warren, A. A. \& Black, T. 1985. A new rhytidosteid (Amphibia, Labyrinthodontia) from the Early Triassic Arcadia Formation of Queensland, Australia, and the relationships of Triassic temnospondyls. - Journal of Vertebrate Paleontology 5: 303-327.

Warren, A. A., Yates, A. M., Damiani, R., Goodwin, M. B. \& Wood, C. B. 1998. The first temnospondyl amphibian from Ethiopia. -

\section{Appendix}

\section{Character-taxon matrix:}

\section{additional taxa/characters to Schoch (2008).}

PGA type. No substantial PGA (0), type 1 (1), type 2 (2). Distribution of states: Outgroups, Sclerocephalus: 0; Uranocentrodon, Lydekkerina: 1; Siderops, Batrachosuchus, Laidleria: 2; Rhytidosteidae: ?; Gerrothorax, Plagiosuchus: 2; Capitosauria, Trematosauroidea: 1; Microposaurus:?

Teeth. Small and numerous, almost all in use (0), much larger, alternate in use (1). All taxa have 0 except $M i$ croposaurus and the Jordan taxon (1).
Inflectosaurus amplus
102030
123456789012345678901234567890
0 ????????????????????????????
0 001?100111?11111????01??0?111
0 101110??????????????02012????
? ?????????????????????????????
$? ? 10$

Neues Jahrbuch für Geologie und Paläontologie Monatshefte 1998: 694-704.

Welles, S. P. 1993. A review of the lonchorhynchine trematosaurs (Labyrinthodontia), and a description of a new genus and species from the Lower Moenkopi Formation of northern Arizona. - Paleobios 14: 1-24.

Witzmann, F. \& Gassner, T. 2008. Metoposaurid and mastodonsaurid stereospondyls from the Triassic-Jurassic boundary of Portugal. Alcheringa 32: 37-51

Witzmann, F. \& Schoch, R. R. 2006. The postcranium of Archegosaurus decheni, and a phylogenetic analysis of temnospondyl postcrania. - Palaeontology 49: 1211-1235.

Yates, A. M. \& Warren, A. A. 2000. The phylogeny of the 'higher' temnospondyls (Vertebrata: Choanata) and its implications for the monophyly and origins of the Stereospondyli. - Zoological Journal of the Linnean Society 128: 77-121.

Zanon, R. T. 1991. Negevodus ramonensis Mazin, 1986, reinterpreted as a temnospondyl, not a placodont. - Journal of Vertebrate Paleontology 11: 515-518.

\section{Microposaurus casei}

$$
102030
$$

123456789012345678901234567890

0 10111??0101??????100??100000?

0 ?111101101111111?11??1010?110

0 10??????????????????02012????

? ????????????????????????????

? ??1

Jordan taxon (SMNS 81772) 102030

123456789012345678901234567890

0 ???????????????????????????

? ?111?????????????????????????

? ??1110???????????????????????

? ?????????????????????????????

? ?11 